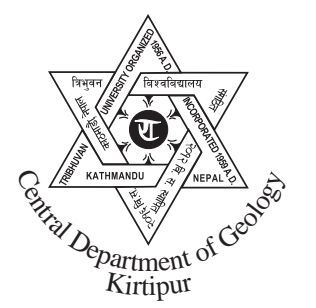

\title{
Sedimentology, dynamics and debris flow potential of Champadevi River, southwest Kathmandu, Nepal
}

\author{
*Naresh Kazi Tamrakar, Achut Prajapati and Suman Manandhar \\ Central Department of Geology, Tribhuvan University, Kathmandu, Nepal
}

\begin{abstract}
Mountainous and hilly regions are potential for debris flows, one of the major forms of natural disasters, which cause serious damage in downstream areas. The southwestern region of the Kathmandu Valley experienced catastrophic flows in the Champadevi River and its two tributaries (the Aitabare and the Raute Rivers) in July 2002. These rivers were investigated for morphologic, hydraulic and sedimentary characteristics to evaluate potential of debris flow in the area.

The Raute and the Aitabare Rivers have tendency of headward erosion due to abrupt drop of gradient down the scarp of the alluvial fan deposit composed of unconsolidated matrix-supported gravel and mud. Because of this tendency, the rivers erode their substrate and banks, and contribute slope movements by sheding a huge amount of clasts and matrix. Therefore, instability condition of rivers and unconsolidated material available in the river courses potentially contribute for debris flow.

The tractive shear stresses in the Aitabare, the Raute and the Champadevi Rivers (1.27, 1.60 and $0.48 \mathrm{KPa}$, respectively) exceeds twice the critical shear stresses required to transport 90th-percentile fraction of the riverbed material $(0.14,0.18$ and 0.11 $\mathrm{KPa})$. The stream powers $\left(10.8,17.2\right.$ and $\left.5.1 \mathrm{~m}-\mathrm{kN} / \mathrm{s} / \mathrm{m}^{2}\right)$ of these rivers also greatly exceed the critical stream powers $(0.21,0.35$ and $0.18 \mathrm{~m}-\mathrm{kN} / \mathrm{s} / \mathrm{m}^{2}$ ) required to initiate traction transport. Because the tractive shear stresses and the stream powers that are achieved during bankfull flow are several times larger than the corresponding critical values, even the flow having stream power exceeding the crital stream power may potentially generate debris flow.
\end{abstract}

\section{INTRODUCTION}

In mountain and hilly regions, debris flow is one of the major forms of natural disasters, which cause serious damage in downstream areas. Several debris flow events occurred in Nepal as a consequence of high intensity rainfalls (Anon 1994; Dangol et al. 1996; Upreti and Dhital 1996; Dangol 1998; Paudel and Thakuri 2006). In 2002, SW part of the Kathmandu Valley experienced several debris flows, of which the event in the Champadevi River at Dhudhpokhari attracted as it damaged road structures and killed one person.

Debris flows have two basic characteristics, muddy debris flow and granular debris flow (Coussot

\footnotetext{
*Corresponding author:

E-mail address: ntamrakar@hotmail.com
}

and Meunier 1996) and are influenced by many factors, among which tectonics in the basin, river dynamics, the source material composition, and the amount of precipitation are important factors. Tectonic development upsets dynamic equilibrium of rivers and unstable rivers with knick points have tendency of headward erosion (Leopold et al. 1964). The present work focuses on the morphologic, hydraulic and sedimentary characteristics of the Champadevi River to evaluate potential of debris flow in the study area.

\section{GEOMORPHOLOGY}

The study area is located in Dudhpokhari, southwest of the Kathmandu Valley (Fig. 1). The topography of the area was surveyed in 2003 at the scale 1:500. Three physiographic regions; hills, 
alluvial fan with scarps and low-lying sedimentation areas characterise the area (Fig. 2). The hills extend SW forming a catchment divide in the Chandragiri Range. The alluvial fan with scarp shows gentle north-facing original slopes. The active scarps are prominent and are incised by the two major tributaries of the Champadevi River (the Aitabare and the Raute Rivers). The steep slope of scarp which are produced by active faults in the study area (Saijo et al. 1995), faces mainly NE. Similar fault scarps have been reported from the Thankot area (Asahi 2003). The middle part of the study area contains an old landslide deposit with gentle slope adjacent to the main scarp. The low-lying sedimentation areas have gentle to very gentle slopes mainly facing NE. These lowlying areas are perhaps the distal part of the alluvial fans, which are covered by the older and the recent debris flow deposits.

The Aitabare and the Raute Rivers originate from the Chandragiri Range in the south of the study area and contribute the Champadevi River that in turn joins the Simle River (a tributary of the Bosan River). The Aitabare and the Raute Rivers have gentle gradients up to the scarp (Fig. 3). The rivers have steep gradient down the scarp, where they produce runs and incise the streambed, thus forming hanging valleys. The headward erosion is continuing upstream of the scarp. The stream gradient significantly diminishes in the Champadevi River where recent debris flow sediment fans out.

\section{RAINFALL}

The maximum and average monthly rainfalls recorded during 1981-2005 in the Thankot Station (DHM, 2006) are shown in Fig. 4a. The maximum monthly rainfall exceeded the highest average rainfall (515 mm) during June-September (622.5-966.7 $\mathrm{mm})$. The rainfall that occurred during the catastrophic flood in 2002 July was $849 \mathrm{~mm}$, and is the rainfall of 24 years of return period based on parametric rainfall-frequency curve derived from log-Pearson Type III distribution (Fig. 4b). The rainfall of 2-years return period is $623.6 \mathrm{~mm}$. As the rainfall of this magnitude exceeds the average rainfall (548 $\mathrm{mm}$ ) recorded during 1981-2005 in the area, such rainfall may be substantial for bankfull flow and increased debris flow potential.

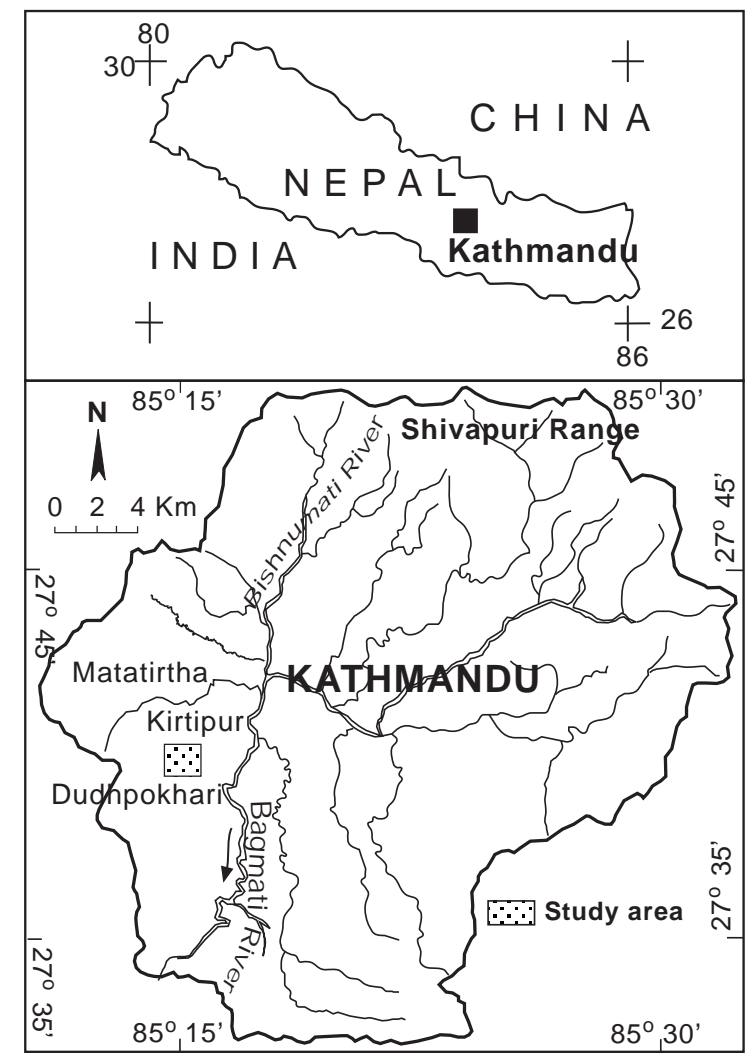

Fig. 1 Location map of the study area

\section{SEDIMENTOLOGY}

\section{Alluvial fan deposit}

The alluvial fan sediment overlies the basement rocks of the Chandragiri Limestone that extend NW-SE and dip gently southwest (Fig. 5). The alluvial fan deposit crops out in the scarp and comprises very thick sequence of unconsolidated, poorly stratified, very poorly sorted and matrixsupported gravel, mud and clay. The strata gently dip 10 degrees north.

The strata in the scarp contain gravel facies and mud facies (Fig. 6a and b). The gravel sub-facies such as matrix-supported massive gravel $(\mathrm{Gmm})$, matrix-supported graded gravel ( $\mathrm{Gmg}$ ) and clastsupported massive gravel $(\mathrm{Gcm})$ are recognized based on Miall's (1996) facies classification. Clasts in all the facies are poorly to very poorly sorted and range in size from pebble to boulder. $\mathrm{Gmm}$ was formed by plastic debris flow (high-strength 




Fig. 2 Engineering geomorphological map of the Dudhpokhari area showing distribution of various slopes

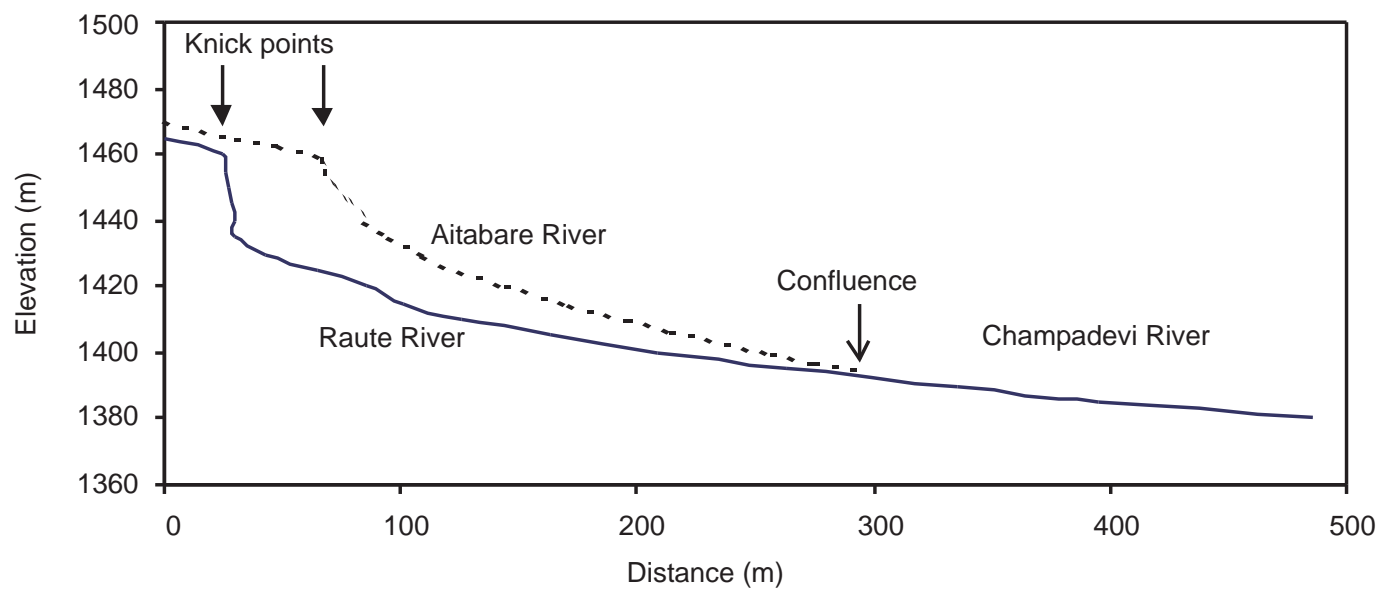

Fig. 3 Profiles of the rivers: (a) Aitabare and (b) Raute River 

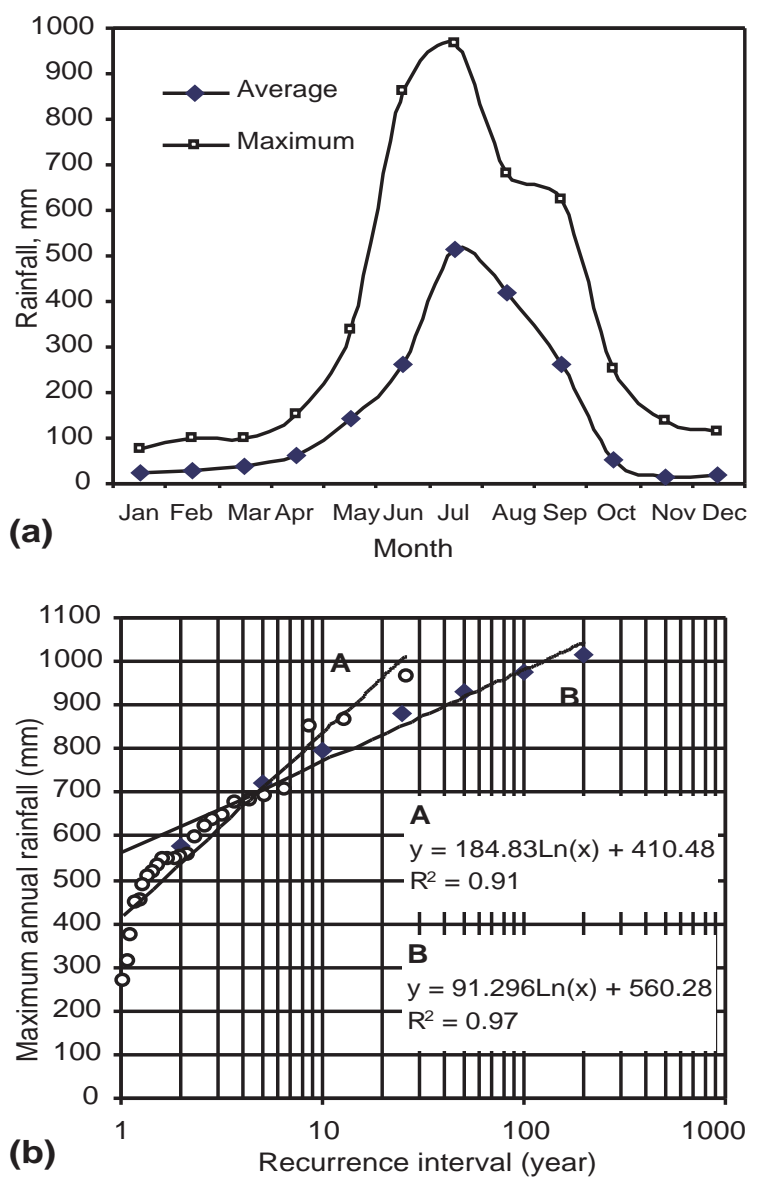

Fig. 4 Rainfall data of the Thankot station (DHM 2006) during 1981-2005: (a) Average and maximum monthly rainfall and (b) Rainfall-frequency curves: A = Empirical rainfall-frequency curve and $\mathrm{B}=$ Parametric rainfall-frequency curve (Log-Pearson Type III distribution)

and viscous). Gmg was produced by psuedoplastic debris flow (low strength), in which rapid flow retards allowing inverse to normal grading. Some Gmg indicates reverse grading produced by low strength and viscous debris flow, in which huge amount of matrix supports clasts in the slurry, and buoyant force exerts dispersion of coarse clast (Coussot and Meunier 1996). The clasts of $\mathrm{Gcm}$ exhibit slight imbrication and indicate pseudoplastic turbulent flow.

Mud facies are massive silt-mud $(F s m)$, massive mud-silt $(F m)$, laminated clay $(F l)$ and laminated dark grey to black clay $(C)$. Fsm is a reddish brown, light brown or yellow mud and indicates abandoned channel deposit. $F m$ is a yellow silt-mud with few lenses of gravel and indicates abandoned channel deposit. $F l$ represents waning flow deposit. The Facies $C$ represents vegetated swamp or marsh deposit and are present in the lower horizon of the sequence.

The association of gravel and mud facies shows that they were deposited in a proximal alluvial fan environment. The alluvial fan deposit forms steep scarps perhaps due to faulting and is a source for large amount of sediment to the rivers, and therefore promotes debris flow in the study area.

\section{Landslide deposit}

The landslide deposit is located in the central region of the study area and shows poorly visible strata, which are exposed in the banks of the Aitabare River, dipping southwest (N58 $\left.{ }^{\circ} \mathrm{E} / 34^{\circ} \mathrm{SW}\right)$ (Fig. 7). In the downstream section, the south dipping strata overlie gently north dipping (10 degrees) black clay layer of the alluvial fan deposit. The south dipping strata show interbedding of gravel, mud and clay (Fig. 8), and extend to the west up to the Raute River. In the eastern part, a road covers the outcrop. The landslide is rotational earth slide, which is perhaps initiated by faulting in the alluvial fan deposit.

Some slope failures occur in the scarp slopes of the Raute River (Fig. 9). The unconsolidated matrixsupported gravel and mud layers when undergo mass movements, contribute enormous debris to the river. The slopes of the Raute River are vulnerable due to high bank heights and active bank erosion. A medium-scale slump is located in the northern part of the study area along the road from Dudhpokhari to Machhegaon.

A debris flow occurred in 2002 July and destroyed several road structures. The Fig. 10 indicates upstream views of the Aitabare and the Raute Rivers (Fig. 10a and b) from the confluence of these rivers and downstream view of the Champadevi River (Fig. 10c) showing abundant debris carried by the rivers.

\section{River morphology}

The cross-sectional survey was carried out in 7 transects in the Aitabare River, 7 in the Raute River 


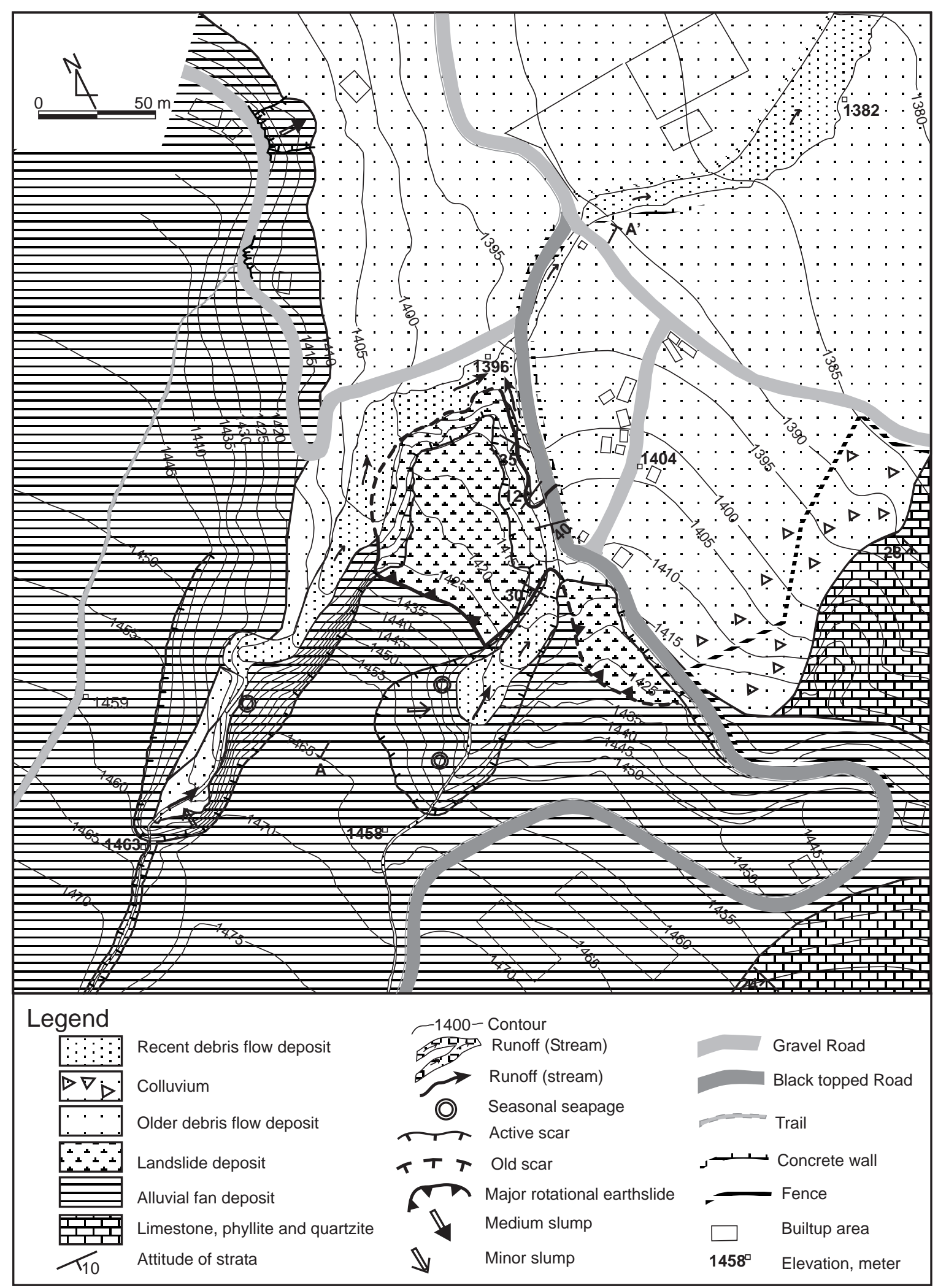

Fig. 5 Engineering geological map of the Dudhpokhari area showing distribution of lithology, structure and landslides; A-A' represents a line of cross-section shown in Fig. 7. 


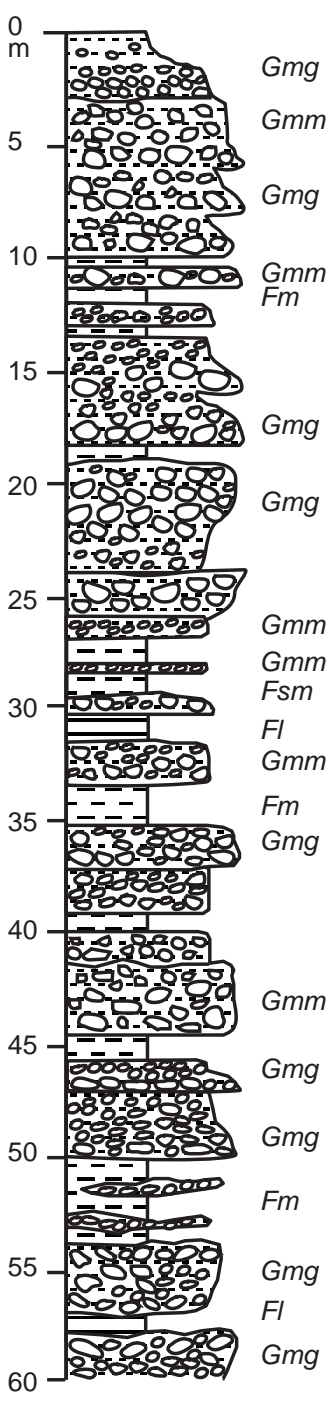

(a)

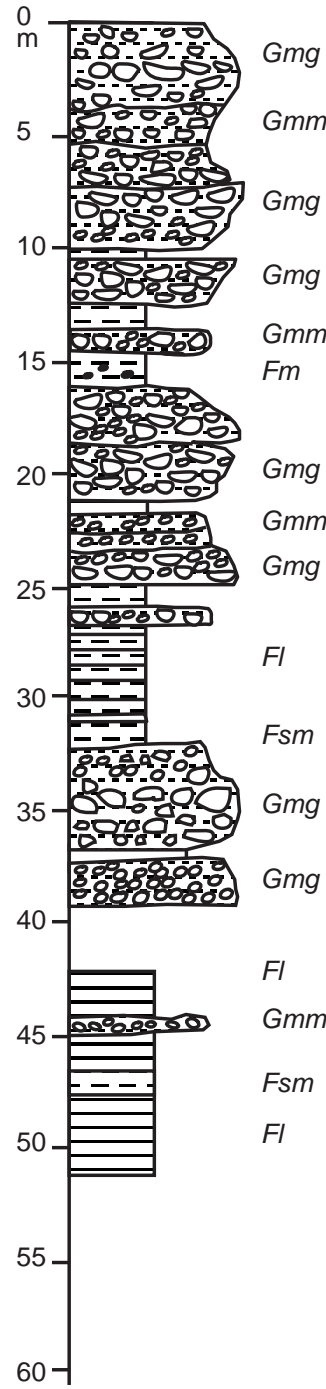

(b)

Fig. 6 Gralphic logs of the alluvial fan deposit: (a) Aitabare river and (b) Raute River

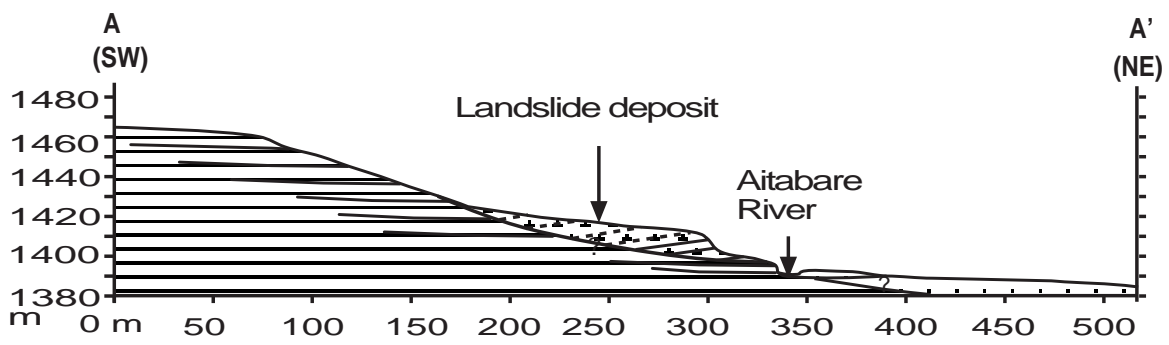

Fig. 7 A profile along A-A' of the Fig. 4 showing landslide deposit 

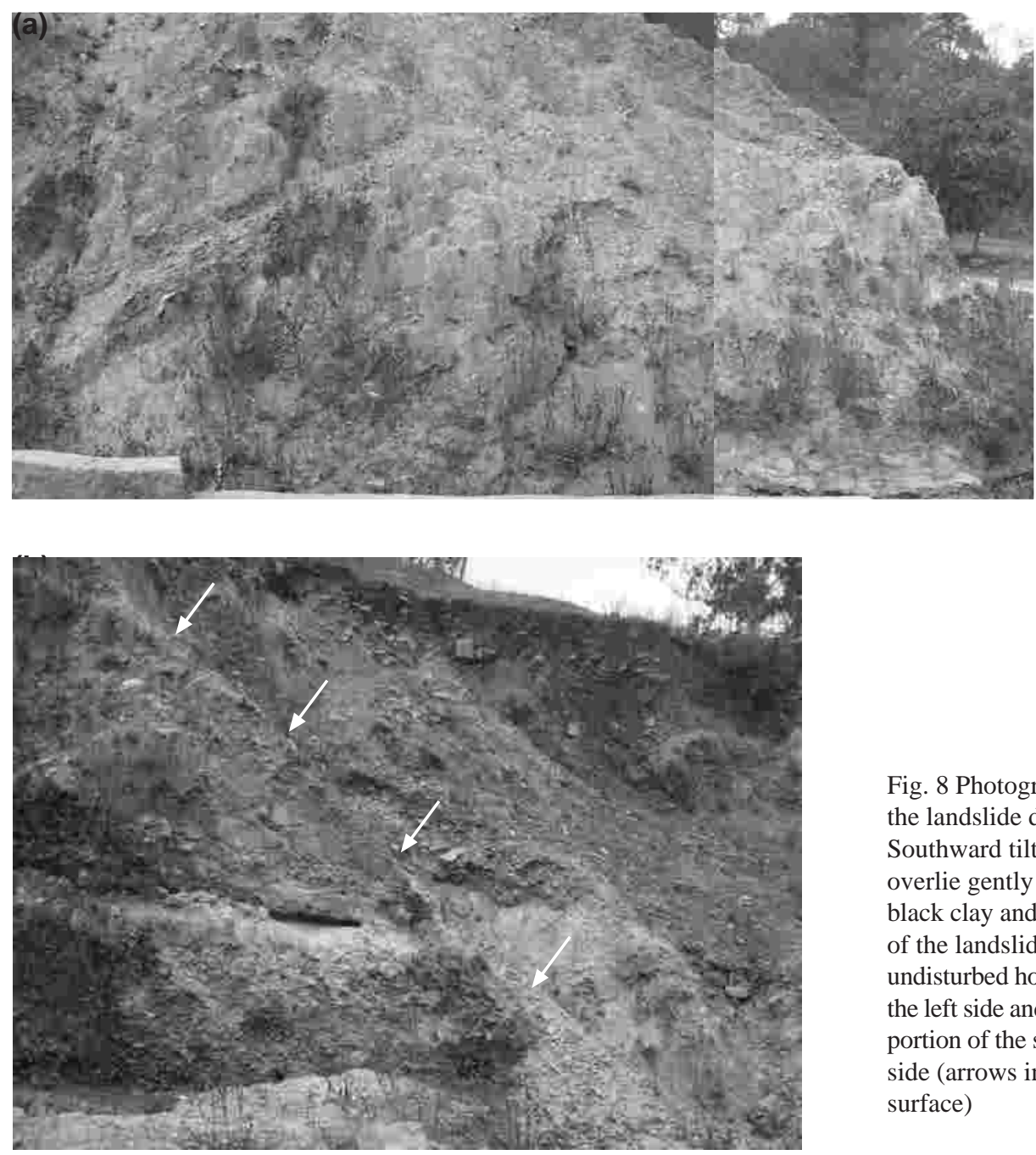

Fig. 8 Photographs showing the landslide deposit: (a) Southward tilted strata which overlie gently north dipped black clay and (b) Slip surface of the landslide showing undisturbed horizontal strata at the left side and disturbed tilted portion of the strata at the right side (arrows indicate slip surface)



Fig. 9 A photograph showing a downstream view of the Raute River indicating headward erosion and slope failure in the righ bank 

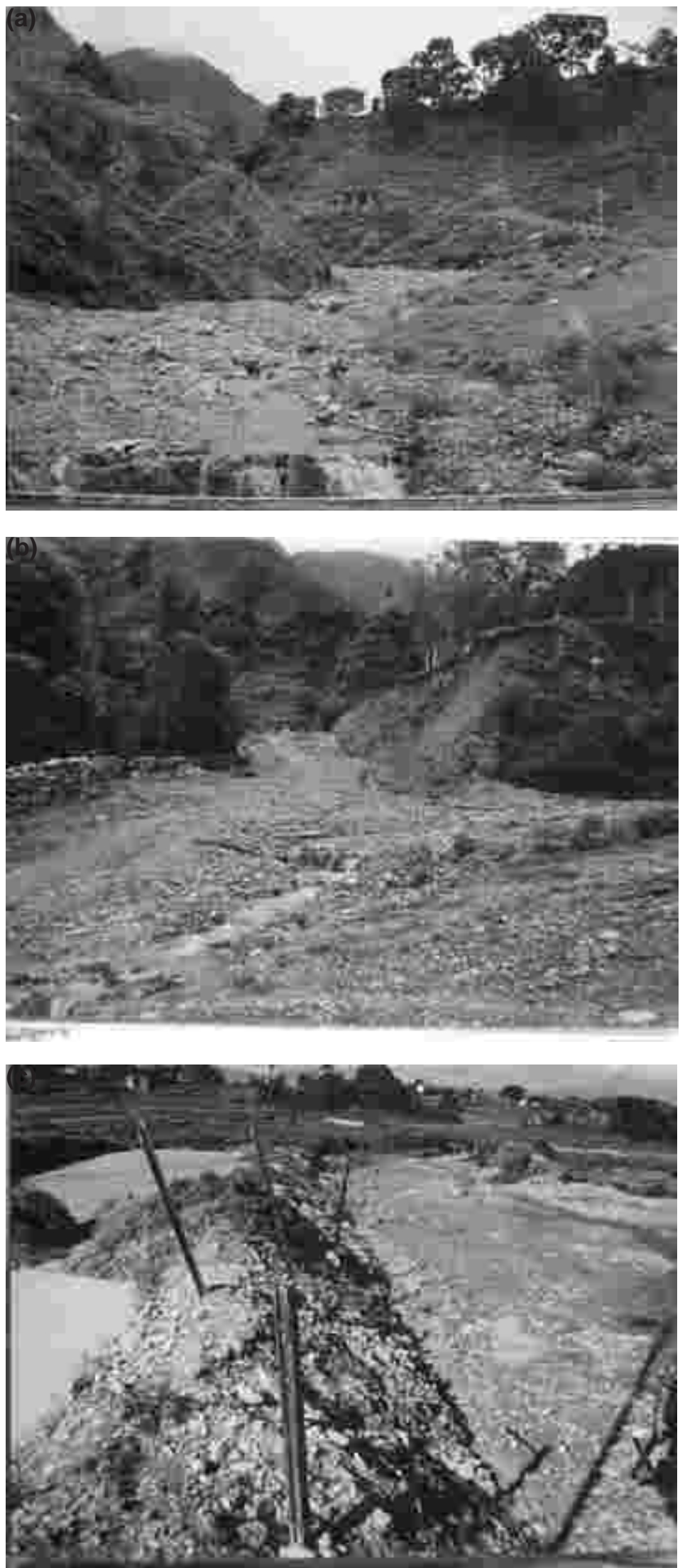

Fig. 10 River segments showing debris on the riverbeds: (a) the Aitabare River (b) the Raute River and (c) the Champadevi River: debris located at closer views of the photographs is pebble-cobble 
and 3 in the Champadevi River. At each of the crosssections, about 40 counts were made based on Wolman's pebble counting technique to characterise the riverbed material size. Morphologic parameters were measured from cross-sections. Fig. 11 represents some of the cross-sections of all the three river segments.

Mean bankfull area (A) of the Aitabare, the Raute and the Champadevi Rivers are 2.88, 8.65, $6.87 \mathrm{~m}^{2}$, respectively (Table 1). Mean width/depth (W/D) ratio and entrenchment ratio (ER) of these rivers are $2.78,6.30$ and 6.16, and 3.36, 1.41 and 1.20, respectively. The Raute and the Champadevi Rivers are wider but more entrenched compared to the Aitabare River. Both rivers also tend to widen downstream.

\section{Riverbed sediment}

The riverbed sediments range from clay to boulder (Fig. 10). The average median size $\left(\mathrm{d}_{50}\right)$ in the Aitabare, the Raute and the Champadevi Rivers are $0.03,0.05$ and $0.04 \mathrm{~m}$, respectively. The coarse fractions from which $90 \%$ of sediments are finer $\left(\mathrm{d}_{90}\right)$ are $0.19,0.25$ and $0.15 \mathrm{~m}$, respectively in the Aitabare, the Raute and the Champadevi Rivers (Table 1). In these rivers, most of the gravel are subangular to subrounded, and are composed of siltstone, quartzite, sandstone, limestone and shale. The composition of the riverbed sediments is similar to those of the alluvial fan deposits. Subrounded to rounded clasts are probably derived from the alluvial fan deposits. Very poorly sorted and heterogeneous distribution of sediments on the riverbed and banks exhibit that the recent debris flows have deposited these sediments.

\section{RIVER DYNAMICS}

\section{Hydraulic parameters}

For each of the rivers, discharge (Q) and velocity (V) were obtained using Manning's equation (Chow, 1959) and continuity equations, respectively as given below:

$$
\begin{aligned}
& Q=\left(A R^{2 / 3} S^{1 / 2}\right) / n \\
& V=Q / A
\end{aligned}
$$

where, A is cross-sectional area at bankfull stage, $\mathrm{R}$ is hydraulic radius, which is a ratio of bankfull area to the sum of width and twice the bankfull depth, $\mathrm{S}$ is average channel slope and $\mathrm{n}$ is Manning's

\begin{tabular}{|c|c|c|c|c|c|c|c|c|c|c|c|c|c|c|c|c|c|c|c|c|}
\hline & \multicolumn{8}{|c|}{ Aitabare River } & \multicolumn{8}{|c|}{ Raute River } & \multicolumn{4}{|c|}{ Champadevi River } \\
\hline & A1 & $\mathrm{A} 2$ & A3 & A4 & A5 & A6 & A7 & lean & $\mathrm{R} 1$ & $\mathrm{R} 2$ & R3 & $\mathrm{R} 4$ & R5 & R6 & $\mathrm{R} 7$ & Mean & $\mathrm{C} 1$ & $\mathrm{C} 2$ & $\mathrm{C} 3$ & Mean \\
\hline $\mathrm{d}_{90}, \mathrm{~m}$ & 0.32 & 0.25 & 0.18 & 0.07 & 0.17 & 0.17 & 0.16 & 0.19 & 0.19 & 0.28 & 0.40 & 0.34 & 0.19 & 0.19 & 0.18 & 0.25 & 0.22 & 0.14 & 0.09 & 0.15 \\
\hline $\mathrm{W}_{\mathrm{bkf}}, \mathrm{m}$ & 40 & 4.15 & 2.90 & 3.70 & 3.00 & 4.20 & 3.10 & .49 & 8.45 & 7.60 & 5.05 & 7.50 & 9.45 & 17.7 & 6.80 & 8.94 & 6.00 & 9.35 & 8.45 & 7.93 \\
\hline $\mathrm{D}_{\max }, \mathrm{m}$ & 1.20 & 1.35 & 1.30 & 1.05 & 1.20 & 1.50 & 1.25 & 1.26 & 1.50 & 1.05 & 1.40 & 1.55 & 1.45 & 1.55 & 1.40 & 1.41 & 1.40 & 1.15 & 1.40 & 1.32 \\
\hline $\mathrm{A}_{\mathrm{bkf}}, \mathrm{m}^{2}$ & 91 & 3.11 & 2.66 & 1.94 & 2.55 & 3.91 & 3.10 & 2.88 & 9.20 & 4.20 & 5.62 & 7.99 & 12.4 & 15.2 & 5.92 & 8.65 & 6.03 & 7.14 & 7.45 & 6.87 \\
\hline $\mathrm{D}_{\mathrm{bkf}}, \mathrm{m}$ & 0.86 & 0.75 & 0.92 & 0.52 & 0.85 & 0.93 & 1.00 & 0.83 & 1.09 & 0.55 & 1.11 & 1.01 & 1.30 & 0.86 & 0.87 & 0.97 & 1.00 & 0.76 & 0.89 & 0.88 \\
\hline $\mathrm{W}_{\mathrm{fpa}}, \mathrm{m}$ & 7.15 & 8.15 & 16.7 & 12.4 & 15.9 & 5.50 & 11.5 & 11.0 & 10.9 & 10.2 & 8.00 & 10.2 & 9.70 & 20.4 & 14.3 & 12.0 & 6.45 & 12.7 & 9.90 & 9.68 \\
\hline W/D & & 3.07 & 2.23 & 3.52 & 2.50 & & 2.48 & & & & & & & & & & & & 6.04 & 6.16 \\
\hline ER & & 1.96 & & 3.35 & 5.30 & & 3.71 & & 1.29 & & 1.58 & & 1.03 & 1.15 & 2.10 & & 1.08 & 1.36 & 1.17 & 1.20 \\
\hline $\mathrm{R}, \mathrm{m}$ & 57 & 0.55 & 0.56 & 0.41 & 0.54 & 0.65 & 0.61 & 0.55 & 0.87 & 0.48 & 0.77 & 0.84 & 1.03 & 0.78 & 0.69 & 0.78 & 0.75 & 0.66 & 0.73 & 0.71 \\
\hline $\mathrm{S}, \mathrm{m} / \mathrm{m}$ & 0.39 & 0.33 & 0.25 & 0.21 & 0.19 & 0.15 & 0.13 & 0.23 & 0.39 & 0.23 & 0.31 & 0.20 & 0.14 & 0.11 & 0.09 & 0.21 & 0.07 & 0.08 & 0.06 & 0.07 \\
\hline $\mathrm{Q}, \mathrm{m}^{3} / \mathrm{s}$ & 30.9 & 30.1 & 22.6 & 12.2 & 18.2 & 27.9 & 20.2 & & 130 & 30.7 & 66.2 & 79.4 & 116 & 108 & 34.9 & & 65.5 & 77.6 & 71.3 & 71.5 \\
\hline $\mathrm{V}, \mathrm{m} / \mathrm{s}$ & 10.6 & 9.67 & 8.49 & 6.27 & 7.14 & 7.15 & 6.51 & & 14.1 & 7.31 & 11.8 & 9.94 & 9.36 & 7.07 & 5.90 & 9.35 & 10.9 & 10.9 & 9.6 & 10.4 \\
\hline, $\mathrm{KPa}$ & 2.15 & 1.80 & 1.38 & 0.84 & 0.98 & 0.93 & 0.79 & & 3.27 & 1.08 & 2.37 & 1.65 & 1.36 & 0.85 & 0.62 & 1.60 & 0.51 & 0.53 & 0.40 & 0.48 \\
\hline $\mathrm{b}, \mathrm{m}-\mathrm{KN} / \mathrm{s} / \mathrm{m}^{2}$ & 22.8 & 17.4 & 11.7 & 5.23 & 7.03 & 6.65 & 5.12 & 10.8 & 46.0 & 7.86 & 27.9 & 16.4 & 12.8 & 6.03 & 3.65 & 17.2 & 5.54 & 5.81 & 3.83 & 5.06 \\
\hline $\mathrm{c}, \mathrm{KPa}$ & 0.23 & 0.18 & 0.13 & 0.05 & 0.12 & 0.12 & 0.12 & 0.14 & 0.14 & 0.20 & 0.29 & 0.25 & 0.14 & 0.14 & 0.13 & 0.18 & 0.16 & 0.10 & 0.06 & 0.11 \\
\hline$/ \mathrm{c}$ & 9.21 & 9.87 & 10.5 & 16.4 & 7.95 & 7.51 & 6.75 & 9.74 & 23.6 & & 8.15 & 6.65 & 9.85 & 6.16 & 4.72 & 9.20 & 3.18 & 5.24 & 6.46 & 4.96 \\
\hline $2 \mathrm{R}_{\mathrm{c}}, \mathrm{m}$ & 0.12 & 0.11 & 0.11 & 0.05 & 0.14 & 0.17 & 0.18 & 0.13 & 0.07 & 0.18 & 0.19 & 0.25 & 0.21 & 0.25 & 0.29 & 0.21 & 0.47 & 0.25 & 0.23 & 0.32 \\
\hline $\mathrm{V}_{\mathrm{c}}, \mathrm{m} / \mathrm{s}$ & 1.91 & 1.66 & 1.40 & 0.77 & 1.42 & 1.47 & 1.44 & 1.44 & 1.35 & 1.91 & 2.30 & 2.22 & 1.61 & 1.66 & 1.66 & 1.82 & 1.99 & 1.42 & 1.09 & 1.50 \\
\hline${ }_{b c}, \mathrm{~m}-\mathrm{KN} / \mathrm{s} / \mathrm{m}^{2}$ & 0.45 & 0.30 & 0.18 & 0.04 & 0.18 & 0.18 & 0.17 & 0.21 & 0.19 & 0.39 & 0.67 & 0.55 & 0.22 & 0.23 & 0.22 & 0.35 & 0.32 & 0.15 & 0.07 & 0.18 \\
\hline
\end{tabular}

Table 1: Morphologic and hydraulic parameters of the rivers 

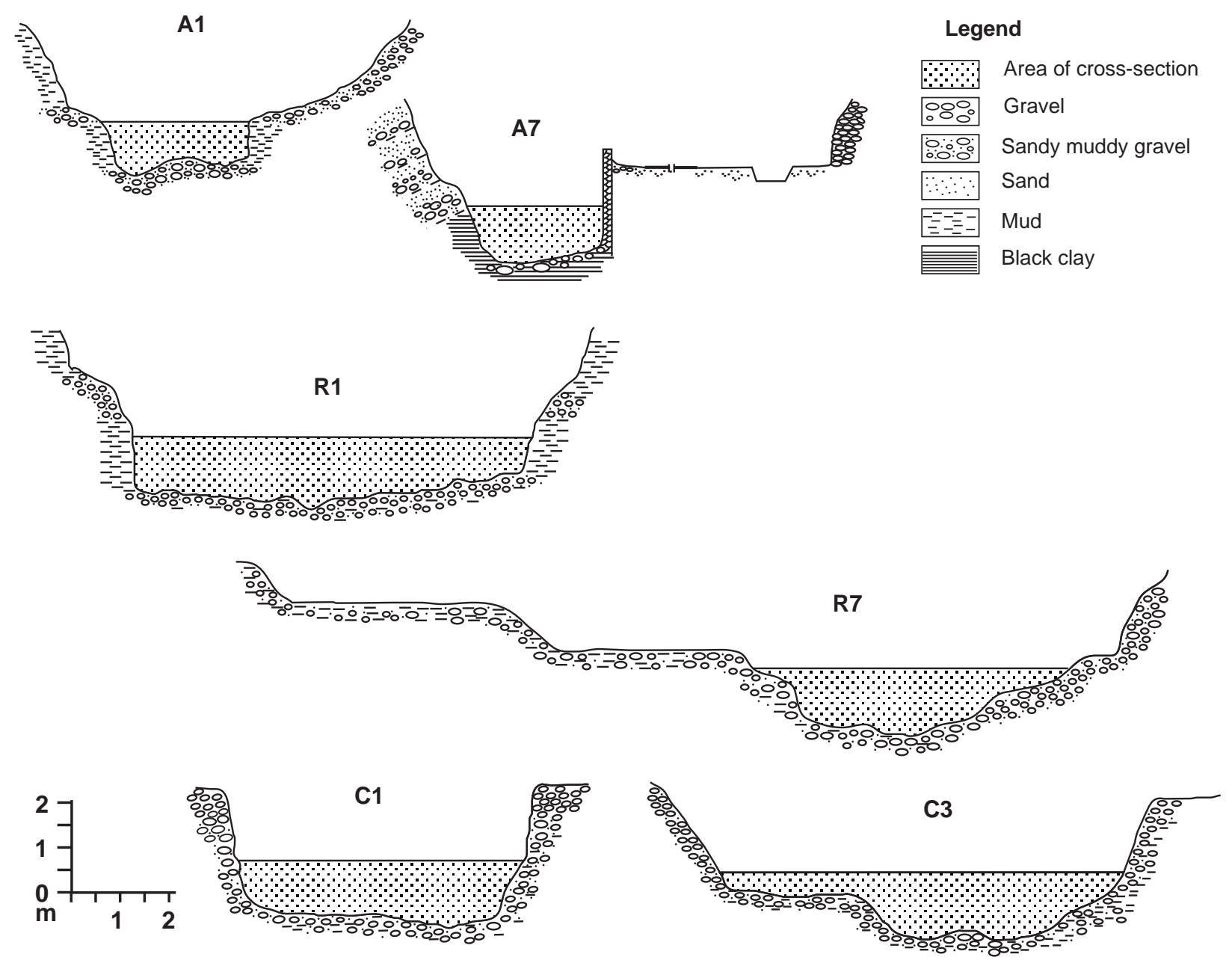

Fig. 11 Cross-sections of the rivers: (a) the Aitabare River, (b) the Raute River and (c) the Champadevi River

roughness coefficient. Manning's roughness coefficient for gravelly rivers was estimated after Rosgen (1994). The n-values for the Aitabare, the Raute and the Champadevi Rivers were 0.04, 0.04 and 0.02 , respectively.

Mean bankfull discharges (Q) calculated for the Aitabare, the Raute and the Champadevi Rivers are $15.1,56.5$ and $26.8 \mathrm{~m}^{3} / \mathrm{s}$, respectively (Table 1 ). Except in the Champadevi River, discharge is not consistent, and tends to vary with change in crosssectional area (A) and slope. Mean bankfull velocities of the Aitabare River, the Raute River and the Champadevi River are 5.2, 6.5 and $3.9 \mathrm{~m} / \mathrm{s}$, respectively. The velocity in each river tends to diminish downstream with increase in cross-sectional area of the rivers.
The average channel slopes (S) are $0.23,0.21$ and $0.07 \mathrm{~m} / \mathrm{m}$ in the Aitabare, the Raute and the Champadevi Rivers, respectively. The upstream portions of both the Raute and the Aitabare Rivers are steep $(0.39 \mathrm{~m} / \mathrm{m})$ and slope diminishes in the downstream portions $(0.13-0.09 \mathrm{~m} / \mathrm{m})$.

\section{Flow competency and capacity}

The ability of a river to transport its total sediment load can be quantified through sediment-transport competency and sediment-transport capacity. Competency of stream is an ability to move particles of given size, whereas capacity is a stream's ability to move a given quantity of sediment. The river competence was evaluated by comparing the tractive shear stress ( ) exerted on the riverbed at bankfull 
discharge with the critical shear stress ( c) required to transport riverbed sediment. The boundary shear stress and critical shear stress were obtained using the following expressions (Shield 1936):

$$
\begin{aligned}
& =\mathrm{RS} \\
& \mathrm{c}=\mathrm{c} g\left(\begin{array}{ll}
\mathrm{s} & ) \mathrm{d}_{\mathrm{i}}
\end{array}\right.
\end{aligned}
$$

where, = unit weight of water $\left(9.81 \mathrm{kN} / \mathrm{m}^{3}\right), \mathrm{R}$ $=$ hydraulic radius $(\mathrm{m}), \mathrm{S}=$ slope of stream $(\mathrm{m} / \mathrm{m})$, $\mathrm{c}=$ Shields parameter $(0.045), \mathrm{g}=$ gravitational constant $\left(9.81 \mathrm{~m} / \mathrm{s}^{2}\right), \mathrm{s}=$ density of sediment $(2650$ $\left.\mathrm{kg} / \mathrm{m}^{3}\right), \quad=$ density of water $\left(1000 \mathrm{~kg} / \mathrm{m}^{3}\right)$, and $\mathrm{d}_{\mathrm{i}}$ $=90$ th - percentile fraction $(\mathrm{m})$. We used d90 instead of $d_{50}$ in this study to evaluate ability of rivers to move the 90th-percentile fraction.

Sediment-transport capacity was evaluated from stream power per unit bed area $(\mathrm{b})$ (hereafter stream power), the force exerted by the flow on sediment times the velocity of the flow, and was obtained using Brookes' (1990) expression:

$$
\text { Stream power, } \quad \mathrm{b}=\mathrm{V}
$$

where, $=$ tractive shear stress $(\mathrm{KPa}), \mathrm{V}=$ velocity $(\mathrm{m} / \mathrm{s})$ and $\quad \mathrm{b}=$ stream power per unit bed area $(\mathrm{m}$ $\mathrm{KN} / \mathrm{s} / \mathrm{m}^{2}$ ).

The average tractive shear stress ( ) and critical shear stress ( c) in the Aitabare, the Raute and the Champadevi Rivers are 1.27, 1.60 and $0.48 \mathrm{KPa}$, and $0.14,0.18$ and $0.11 \mathrm{KPa}$, respectively (Table 1). The ratio / c diminishes from the Aitabare River (9.7) or the Raute River (9.2) to the Champadevi River (5.0). The $\mathrm{b}$ of the Aitabare, the Raute and the Champadevi River are 10.8, 17.2 and $5.1 \mathrm{~m}$ $\mathrm{kN} / \mathrm{s} / \mathrm{m}^{2}$, and critical stream powers ( bc) are 0.21 , 0.35 and $0.18 \mathrm{~m}-\mathrm{kN} / \mathrm{s} / \mathrm{m}^{2}$, respectively. The critical stream powers $(\mathrm{bc})$ are significantly lower than the $b$.

The tractive shear stress as large as twice the critical shear stress is sufficient to move the riverbed material. Because the tractive shear stress and $b$ that have been achieved during bankfull flow are several times larger compared to the corresponding critical values, all the rivers, therefore, are able to transport sediments. However, the competency and the rate of transport to move $\mathrm{d}_{90}$ diminish from the Aitabare River or the Raute River to the Champadevi River. At much larger hydraulic radius in bankfull flow and corresponding tractive shear stress and velocity, stream power becomes large, and sediment concentration in a flow may increase giving rise to a viscous debris flow. Increase in hydraulic radius probably corresponds to the increase in rainfall in the study area. But the water level rise in the rivers can not be predicted from the rainfall data as no gauge station exists in the study area. The water level in the rivers may depend on infiltration capacity and degree of saturation of the terrain, and perhaps on the amount of rainfall against time. Since, tractive shear stresses and stream powers are much larger compared to the critical shear stresses and critical stream powers, the hydraulic radii required for moving the existing sediment of the riverbeds are quite low. As this hydraulic depth is achieved even at lower level than at the bankfull condition, the river is potentially dangerous for debris flow. The rainfall amount of approximately $400 \mathrm{~mm} / 24 \mathrm{hrs}$ seems substantial for debris flow to occur and as such rainfall tends to occur at every 2-3 years interval, the study area is potential for debris flow events to occur.

The gente alluvial fan surface forms transport zone. The segments of the Aitabare and the Raute Rivers between the scarp and their confluence are potential for debris flow and locate in debris flow zone. This zone has steep topography and sediments of huge boulders (>1.5 m) to fines. Topographically high areas adjuscent to the river although are not as potential as the river channels themselves, are also located in this zone because any landslide may transfer to debris flow. The sediment flow zone locates downstream of the Champadevi River where an accumulation surface is rough with large sediments (upto $1 \mathrm{~m}$ ) with abundant fines.

\section{CONCLUSIONS}

1. The past and the recent events of debris flows and landslides indicate that the Champadevi River basin is vulnerable to slope movements. The Raute and the Aitabare Rivers show tendency of headward erosion against abrupt drop of stream gradient in the scarp. Because of this tendency, the rivers erode sediments from their substrate and banks, and 
contribute for slope movements.

2. Presence of unconsolidated matrix-supported gravel and mud layers in the banks of the incising rivers pose debris flow hazard because huge amount of clasts and matrix have been released by slope failure and slumps. Therefore, instability condition of rivers and unconsolidated material available in the rivers potentially contribute for debris flow.

3. The tractive shear stresses $(1.27,1.60$ and 0.48 $\mathrm{KPa}$, respectively in the Aitabare, the Raute and the Champadevi Rivers) largely exceed twice the critical shear stresses required to move d90 of the existing riverbed material $(0.14,0.18$ and $0.11 \mathrm{KPa})$. The stream powers of these rivers $(10.8,17.2$ and 5.1 $\mathrm{m}-\mathrm{kN} / \mathrm{s} / \mathrm{m}^{2}$ ) greatly exceed the critical stream powers of the same river $\left(0.21,0.35\right.$ and $\left.0.18 \mathrm{~m}-\mathrm{kN} / \mathrm{s} / \mathrm{m}^{2}\right)$. Because the conditions achieved during bankfull flow are several times larger compared to the corresponding critical values ( $c$ and $b c$ ) for $d_{90}$, the rivers are potential for debris flow. The ability of the rivers to transport sediment diminishes from the Aitabare and the Raute Rivers to the Champadevi River.

4. The stream powers exceeding the critical stream powers begin traction transport, but at much larger stream powers in the Aitabare and the Raute Rivers, sediment concentration in flow possibly increases and traction transport transfers to debris flow. The critical stream power at this transfer probably lies between bc90 and b.

\section{ACKNOWLEDGEMENTS}

The authors thank the head of the Department of Geology, Tribhuvan University and M. B. Shrestha, Gifu University, Japan for providing support of survey instruments.

\section{REFERENCES}

Anon, 1994. Preliminary survey of debris flows and landslides in the Palung Khola and the Manahari Khola (Makawanpur District, Central Nepal). Technical report of Water Induced Disaster Prevention Technical Centre and Tribhuvan University.

Asahi, K., 2003. Thankot active fault in the Kathmandu
Valley, Nepal Himalaya. Journal of Nepal Geological Society, V. 28, pp. 1-8.

Brookes, A., 1990. Restoration and enhancement of engineered river channels: some European experiences. Regulated Rivers: Research and Management, V. 5, No. 1, pp. 45-56.

Chow, V.T., 1959. Open channel hydraulic. McGrawHill, Inc. New York.

Coussot, P. and Meunier, M., 1996. Recognition, classification and mechanical description of debris flows. Earth Science Reviews, V. 40, pp. 209-227.

Dangol, V., 1998 Sediment balance in Kamala River watershed, Eastern Nepal, after high intensity rainfall of July 1993 and August 1995. International workshop documents, Asian Institute of Technology, Bankok, Thailand, pp. 31-37.

Dangol, V., Thankur, K.C., Ulak, P.D., Nepali, D.B., Rai, S.M., Joshi, B.M., 1996. Landslides and Debris flows of July 1993 in the upper Eastern Rapti Basin, Central Nepal. Bulletin of Department of Geology, Tribhuvan University, Kathmandu, Nepal, V. 5, pp. 61-75.

DHM, 2006. Rainfall data of Thankot station recorded during 1981-2005. Electronic data obtained from Department of Hydrology and Meteorology, Nepal Government, Babar Mahal, Kathmandu, Nepal.

Leopold, L.B., Wolman, M.G. and Miller, J.P., 1964. Fluvial processes in geomorphology. W. H. Freeman \& Co., San Fransisco, U.S.A., 522p.

Miall, A.D., 1996. The geology of fluvial deposits, sedimentary facies, basin analysis, and petroleum geology. Springer-Verlag, Berlin, Heidelberg, 582p.

Paudel, P. and Thakuri, A.B.C., 2006. Engineering geological characteristics of Matatirtha debris flow, Kathmandu. Bulletin of Nepal Geological Society, v. 23, pp. 43-46.

Rosgen, D.L., 1994. A classification of natural rivers, Cantenna, V. 22, pp. 169-199.

Saijo, K., Kimura, K., Dongol, G., Komatsubara, T. and Yagi, H., 1995. Active faults in southwestern Kathmandu Basin, Central Nepal. Journal of Nepal Geological Society, V. 11, Special Issue, pp. 217-224.

Shields, A., 1936. Application of similarity principles and turbulence research to bed-load movement. In: W.P. Ott and J.C. Uchelen (translators), Mitt. Press. Verschsanst., Berlin. Wasserbau Schiffbau. California Institute of Technology, Pasadena. CA, Report No. $167,43 p$.

Upreti, B.N., Dhital, M.R., 1996. Landslide studies and Management in Nepal. International Centre for Integrated Mountain Development, Kathmandu, Nepal, $87 \mathrm{p}$. 